\title{
小児軽症頭部外傷例の視床下部，下垂体，副腎系の内分泌動態
}

\author{
森山匠川場知幸
}

\section{Endocrinological Changes in the Hypothalamic, Pituitary, and Adrenal Systems of Children after a Minor Head Injury}

by

Takumi Moriyama, M.D., and Tomoyuki Kawaba, M.D.

from

Division of Neurosurgery, Fuchu Keijinkai Hospital

Endocrinological changes of the hypothalamic, pituitary, and adrenal systems in children up to the age of 15 years have been studied in 30 cases of a minor head injury that caused vomiting. At the time of vomiting, the serum levels of $\mathrm{ADH}$ (antidiuretic hormone), ACTH (adrenocorticotropic hormone), cortisol, renine, epinephrine, norepinephrine, and the keton body were found to be high. These levels returned to their normal values, however, after vomiting ceased.

The abnormal endocrinological changes that were detected in this study are similar to the endocrinological changes seen in children who manifest cyclic, acetonemic vomiting.

(Received November 29, 1993 ; accepted February 18, 1994)

Key words : minor head injury, children, ACTH, ADH, catechalamine

Jpn J Neurosurg (Tokyo) $3: 456-458,1994$

\section{はじめに}

小児軽症頭部外傷の臨床的特徴の一つとして反復性嘔 吐が知られているが，その発生機序については周期性嘔 吐症との関連を指摘するものも多(1)4)5). 従来より周期 性嘔吐症ではケトーシスのほか, 視床下部, 下垂体, 副 腎系に内分泌動態の異常をきたすことが知られてお $\eta^{3)}$, 外傷後嘔吐症患児においても同様な異常をきたす ことが考えられる。しかし，本症患児の系統的研究はな い。われわれは本症患児について視床下部，下垂体，副 腎系の内分泌動態を検討し，興味ある知見を得たので報 告する.

\section{対象と方法}

対象は 15 歳以下の男児 25 例, 女児 5 例の計 30 例であ
る.いずれも受傷直後の意識消失はないか, あっても 30 分以内の軽症頭部外傷例で, 一定時間後に嘔気, 嘔吐な どをきたしたものである，なお，患児の両親ないし代理 人に検査の主旨を十分説明し, 了解を得られた症例のみ を対象とした。

採血は原則として午前 9 時〜11 時の間に行い, 血中 $\mathrm{ADH}$ (antidiuretic hormone), ACTH (adrenocorticotropic hormone), cortisol, renin, epinephrine, norepinephrine, dopamine (DA), 血糖, 血清浸透圧, $\mathrm{Na}$, ケトン分画を測定した。 また尿中ケトンも測定した。 これらの検査は嘔吐消失 $7 〜 21$ 日後に再検した。

なお, 測定値は平均値士標準偏差 $($ mean $\pm \mathrm{SD})$, 中央 值 (Med) で表わした。統計処理は，data に正規性，等 分散性がやや乏しい傾向が認められたので，non-parametorical statistics を使用し，5\%以下を有意とした。 

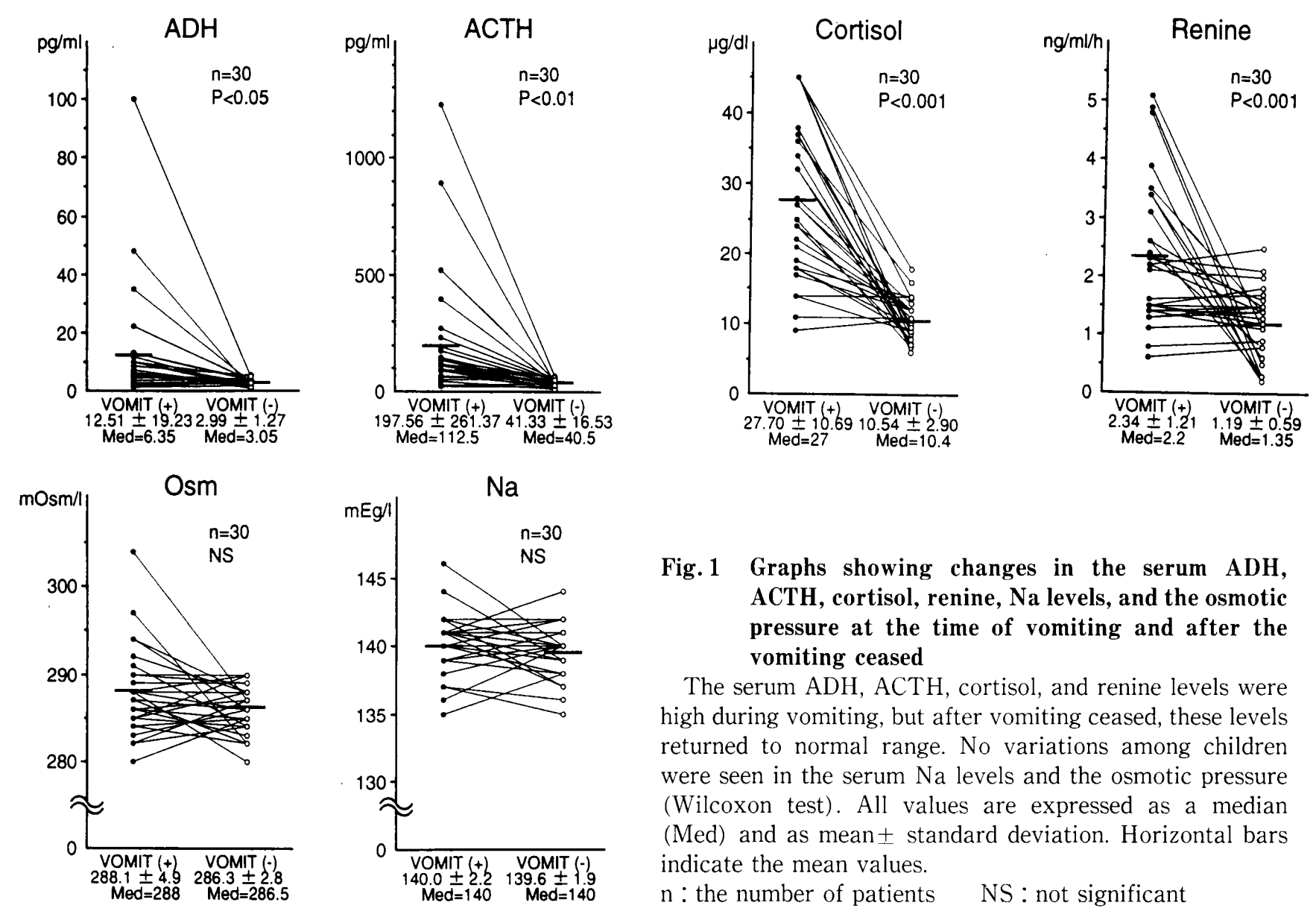

Fig. 1 Graphs showing changes in the serum ADH, ACTH, cortisol, renine, Na levels, and the osmotic pressure at the time of vomiting and after the vomiting ceased

The serum $\mathrm{ADH}, \mathrm{ACTH}$, cortisol, and renine levels were high during vomiting, but after vomiting ceased, these levels returned to normal range. No variations among children were seen in the serum $\mathrm{Na}$ levels and the osmotic pressure (Wilcoxon test). All values are expressed as a median (Med) and as mean \pm standard deviation. Horizontal bars indicate the mean values.

$\mathrm{n}$ : the number of patients NS : not significant
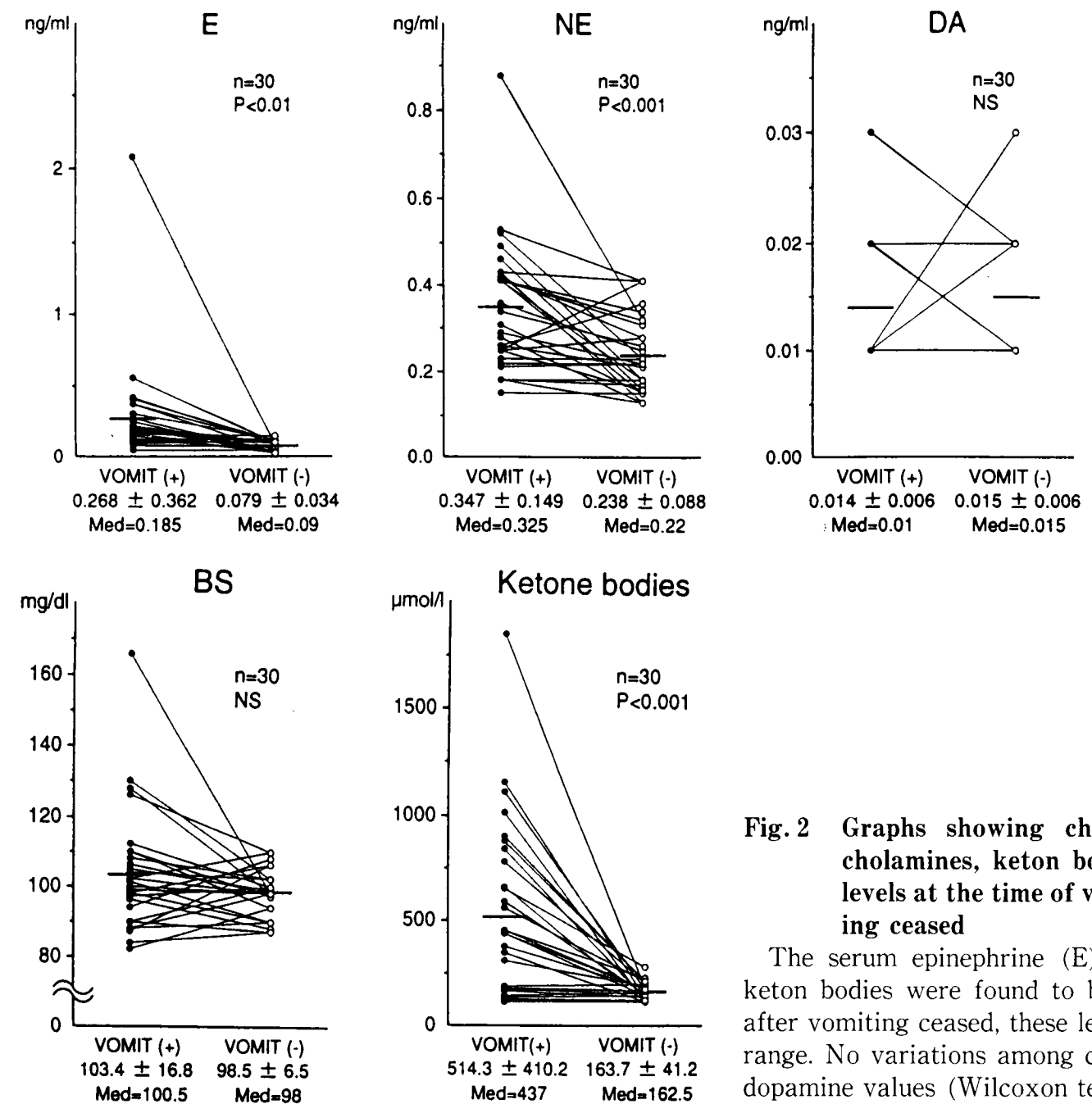

Fig. 2 Graphs showing changes in the serum catecholamines, keton bodies, and blood sugar (BS) levels at the time of vomiting and after the voniting ceased

The serum epinephrine (E), norepinephrine (NE), and keton bodies were found to be high during vomiting, but after vomiting ceased, these levels returned to their normal range. No variations among children were seen in BS and dopamine values (Wilcoxon test). 


\section{結 果}

1 血中 $\mathrm{ADH}, \mathrm{ACTH}$, cortisol, renin, $\mathrm{Na}$, 血清浸透圧の变化 (Fig. 1)

血中 $\mathrm{ADH}$ は嘔吐時 $12.51 \pm 19.23(\mathrm{Med}=6.35) \mathrm{pg} / \mathrm{m} l$ と高く, 嘔吐消失後は $2.99 \pm 1.27(\mathrm{Med}=3.05) \mathrm{pg} / \mathrm{m} l$ に 低下し (Wilcoxon test, $\mathrm{p}<0.05), \mathrm{ACTH}$ も嘔吐時 $197.6 \pm 261.4(\mathrm{Med}=112.5) \mathrm{pg} / \mathrm{m} l$ と高く, 嘔吐消失後 には $41.33 \pm 16.53(\mathrm{Med}=40.5) \quad \mathrm{pg} / \mathrm{m} l$ に低下した (Wilcoxon test, $\mathrm{p}<0.01$ ). cortisol は嘔吐時 $27.70 \pm$ $10.69(\mathrm{Med}=27) \mu \mathrm{g} / \mathrm{d} l$ と高く, 嘔吐消失後は $10.54 \pm$ $2.90($ Med $=10.4) \mu \mathrm{g} / \mathrm{d} l$ に低下し (Wilcoxon test, p $<0.001)$, 血清レニン活性も嘔吐時 $2.34 \pm 1.21(\mathrm{Med}=$ 2.2) $\mathrm{ng} / \mathrm{m} l / \mathrm{h}$ と高 $<$, 嘔吐消失後は $1.19 \pm 0.59(\mathrm{Med}=$ 1.35) $\mathrm{ng} / \mathrm{m} l / \mathrm{h}$ と低下した (Wilcoxon test, $\mathrm{p}<0.001$ ). 血清 $\mathrm{Na}$, 血清浸透圧には有意な変動はなかった（Wilcoxon test).

2 血中 catecholamine, 血中ケトン分画, 血糖の变動および尿中ケトン (Fig. 2)

epinephrine は嘔吐時 $0.268 \pm 0.362(\mathrm{Med}=0.185) \mathrm{ng} /$ $\mathrm{m} l$ と高く, 嘔吐消失後は $0.079 \pm 0.034(\mathrm{Med}=0.09) \mathrm{ng} /$ $\mathrm{m} l$ と低下し (Wilcoxon test, $\mathrm{p}<0.01$ ), norepinephrine も嘔吐時 $0.347 \pm 0.149(\mathrm{Med}=0.325) \mathrm{ng} / \mathrm{m} l$ と高く, 嘔 吐消失後は $0.238 \pm 0.088(\mathrm{Med}=0.22) \mathrm{ng} / \mathrm{m} l$ と低下し た。また嘔吐時尿ケトン陽性者は 30 例中 13 例 (43\%) にすぎなかったが，血中ケトン体は 30 例中 28 例 (93\%) が異常高値を示し，その值は $514.3 \pm 410.2(\mathrm{Med}=437)$ $\mu \mathrm{mol} / l$ で, 嘔吐消失後には $163.7 \pm 41.2(\mathrm{Med}=162.5)$ $\mu \mathrm{mol} / l$ と低下した (Wilcoxon test, $\mathrm{p}<0.001$ ). しかし, dopamineや血桾值には一定の変動はなかった (Wil- coxon test).

\section{考 察}

小児軽症頭部外傷後の嘔吐発生機序については, (1) 自 律神経系の調節障害説 ${ }^{1)}$, (2) ショックによる代謝系障害 説 ${ }^{4)}$, (3) 嘔吐中枢の機能障害説 ${ }^{2)}$, (4) 視床下部の機能障害 説 ${ }^{5)} 4$ 説が代表的である.しかし，これらの説では本患 児の内分泌代謝の系統的検討はなかった，今回，外傷性 嘔吐患児において, 嘔吐時に視床下部・下垂体・副腎系 の内分泌動態に著しい異常のあることや，ほぼ全例にケ トーシスが出現することが，われわれの検討で初めて明 らかになった。しかもこれらの異常は，すでに報告され ている周期性嘔吐症患児の異常3)とほぼ同一で, 嘔吐消 失後に速やかに消失することから,一過性の機能的異常 と推察された。

稿を終えるにあたり,ご校閲を賜りました久留米大学脳神経外科 重森 稔教授に深謝いたします。

\section{文献}

1）益沢秀明, 青木信彦, 清水 隆, 河野 宏: 小児頭部外 傷後嘔吐症. 脳・神経外傷 $5: 31-35,1973$.

2）長縄伸幸, 高木卓爾, 守野 晃, 永井 肇：小児に抢け る軽症頭部外傷後の嘔吐. 小児の脳神経 4:151-157, 1979.

3）荻原正明, 有瀧世界爺, 本多輝男: 周期性嘔吐症の最近 の諸問題. 小児科 $27: 1355^{-1365,} 1986$.

4）上津原甲一, 朝倉哲彦, 谷川達也, 川島弘子, 喜多村孝 一：幼少児頭部外傷と嘔吐について. 脳と発達 $\mathbf{5}$ : 334-338, 1973 .

5）山本豊城, 長田 裕, 佐藤慎一, 田中清明, 伴 貞彦, 長久雅博, 尾形誠宏：小児軽症頭部外傷と嘔吐. 脳外 $7: 363-369,1979$.

要

旨

小児軽症頭部外傷例の視床下部，下垂体，副腎系の内分泌動態

森山匠川場 知幸

湢吐を伴う小児軽症頭部外傷例において, 視床下部, 下垂体, 副腎系の内分泌動態について検討し た. 対象は嘔吐を伴う15歳以下の軽症頭部外傷 30 例である. 嘔吐時 ADH, ACTH, cortisol, renine, epinephrine, norepinephrine の血中しべルは高＜，䧢吐消失後にこれらは低下し， 正常域となつた．これら内分泌動態の異常は周期性嶇吐症患児にみられる異常とほぼ同一で, しかも 嘔吐消失後に速やかに消失することから，一過性の機能的異常と推察された。 